\title{
VALIDATION OF A COMMUNITY COLLECTIVE EFFICACY SCALE IN AN AFRICAN CONTEXT
}

Wilmien van Straten

Mini-dissertation (article format) submitted in partial fulfilment of the requirements for the degree Master of Arts in Clinical Psychology at the NorthWest University (Potchefstroom Campus)

Supervisor: Dr. Q.M. Temane

Co-Supervisor: Prof. M.P. Wissing

Potchefstroom

2007 


\section{TABLE OF CONTENTS}

1. Acknowledgements 3

2. Summary 4

3. Opsomming 6

4. Preface 8

4.1 Article format $\quad 8$

4.2 Selected journal $\quad 8$

4.3 Letter of consent $\quad 8$

4.4 Page numbering $\quad 8$

5. Manuscript 10

5.1 Instructions to authors: South African Journal of Psychology $\quad 11$

5.2 Validation of a community collective efficacy scale in an African context

Manuscript title, authors and addresses 13

Abstract $\quad 14$

Introduction and background 15

Method: Design 19

Participants $\quad 19$

Measuring instruments $\quad 20$

Procedure $\quad 22$

Ethical aspects _ _ $\quad 23$

Data analysis 23

Results: Descriptive statistics of measures used in the study 24

Criterion-related validity of the CCES 24

Confirmatory factor analysis $\quad 25$

Discussion $\quad 26$

References $\quad 29$

List of tables:

Table $1 \quad 34$

Table 2

Table $3 \quad 36$

Appendix A:

Community Collective Efficacy Scale (abridged):

English version 


\section{ACKNOWLEDGEMENTS}

I would like to express my gratitude to the following persons and institutions for their involvement and contribution:

My supervisor, Dr. Q.M. Temane, for his assistance, guidance, insight and patience (with all my numerous questions!).

My co-supervisor, Prof. M.P. Wissing, for her assistance, guidance and input.

Jovika, Sinette, Carelyn and Sandra for their assistance and support as part of the research team.

The financial assistance of the National Research Foundation: Division for Social Sciences and Humanities towards this research is hereby acknowledged. Opinions expressed and conclusions arrived at are those of the authors and are not necessarily to be attributed to the National Research Foundation.

All the research participants, without whom this study would not have been possible.

Mr. Johan Blaauw for language editing.

Special thanks to my parents and the rest of my family for their support and encouragement.

Werner for inspiration and encouragement.

Friends and colleagues who supported me.

My Heavenly Father. 


\section{SUMMARY}

\section{VALIDATION OF A COMMUNITY COLLECTIVE EFFICACY SCALE IN AN AFRICAN CONREXT}

Key words: African context; psychological well-being; self-efficacy; collective efficacy; psychometric properties; reliability; validity

There is a lacuna in the literature regarding the measurement of community collective efficacy, especially in an African context. Previously, a variety of studies have used and validated self-efficacy measures in Western social contexts (Chen, Gully \& Eden, 2001; Schwarzer \& Jerusalem, 1993; Carroll, Rosson \& Zhou, 2005). Findings from crosscultural psychology indicate that human behaviour is not acontextual (Devonport \& Lane, 2006; Karademas, 2006; van de Vijver \& Leung, 1997). Thus, this study was an attempt to explore the validation of a community collective efficacy scale in an African cultural context.

A sample of 1050 Setswana-speaking participants was drawn from both urban and rural areas. The participants came from a relatively more collectivistic cultural context. Measuring instruments such as the Community Collective Efficacy Scale (Carroll, Rosson \& Zhou, 2005), the Generalised Self-Efficacy Scale ( Schwarzer \& Jerusalem, 1993), the New General Self-Efficacy Scale (Chen, Gully \& Eden, 2001), the Sense of Coherence Scale (SOC-29) (Antonovsky, 1987, 1993) the Affectometer 2 (short version) (AFM) (Kammann \& Flett, 1983), the Satisfaction with Life Scale (SWLS) (Diener, Emmons, Larsen \& Griffin, 1985) and the General Health Questionnaire (GHQ-28) (Goldberg \& Hillier, 1979) were used in this study. Criterion-related validity of the CCES was established. Construct validity was determined by conducting confirmatory and exploratory factor analyses on the community collective efficacy scale.

Results indicated a Cronbach alpha reliability coefficient of 0.72 for the CCES and an acceptable inter-item correlations. Criterion-related validity was satisfactory. 
Confirmatory factor analysis indicated a good fit and exploratory factor analysis yielded only one factor on the items used.

The results of the study indicated that overall, the CCES may be a valid measure of community collective efficacy in the sample selected for the study based on parameter estimates. Future studies should further validate this instrument cross-culturally in various African groups and contexts. 


\section{OPSOMMING}

\section{VALIDERING VAN 'n GEMEENSKAPSKOLLEKTIEWE EFFEKTIWITEITSKAAL}

Sleutelwoorde: Afrika-konteks; psigologiese welstand; selfeffektiwiteit; kollektivistiese effektiwiteit; psigometriese eienskappe; betroubaarheid; geldigheid.

Daar is ' $n$ leemte in die literatuur aangaande die meting van 'n gemeenskap se kollektiewe effektiwiteit, veral in 'n Afrika-konteks. Voorheen is 'n verskeidenheid van studies gedoen en gevalideer om selfeffektiwiteit in 'n Westerse sosiale konteks te meet (Chen, Gully \& Eden, 2001; Schwarzer \& Jerusalem, 1993; Carroll, Rosson \& Zhou, 2005). Bevindinge vanuit kruiskulturele sielkunde dui daarop dat menslike gedrag nie akontekstueel is nie (Devonport \& Lane, 2006; Karademas, 2006; van de Vijver \& Leung, 1997). Hierdie studie was dus 'n poging om die validasie van 'n gemeenskapskollektiwistiese effektiwiteitskaal in 'n Afrika- kulturele konteks te eksploreer.

'n Steekproefpopulasie van 1050 Setswana-sprekende deelnemers is geïdentifiseer vanuit beide stedelike en plattelandse gebiede. Die deelnemers is gekies vanuit ' $n$ relatief meer kollektivistiese kulturele konteks. Metingsinstrumente soos die Community Collective Efficacy Scale (abridged) (CCES) (Carroll, Rosson \& Zhou, 2005), die Generalized SelfEfficacy Scale (GSE) (Schwarzer \& Jerusalem, 1993), die New General Self-Efficacy Scale (NGSE) (Chen, Gully \& Eden, 2001), die Sense of Coherence Scale (SOC-29) (Antonovsky, 1987, 1993), die Affectometer 2 (short version) (AFM) (Kammann \& Flett, 1983), die Satisfaction with Life Scale (SWLS) (Diener, Emmons, Larsen \& Griffin, 1985) en die General Health Questionnaire (GHQ-28) (Goldberg \& Hillier, 1979) is in hierdie studie gebruik. Kriteriumverwante geldigheid van die CCES is bepaal. Konstrukgeldigheid is bepaal deur bevestigende faktoranalise en eksplorerende faktoranalise toe te pas op die gemeenskapskollektiewe effektiwiteitskaal. 
Resultate het 'n. Cronbach alpha-betroubaarheidskoëffisient van 0.72 en aanvaarbare inter-itemkorrelasies aangedui. Kriteriumverwante geldigheid was bevredigend. Bevestigende faktoranalise het 'n goeie passing aangedui en eksplorerende faktoranalise het een faktor opgelewer uit die items wat geselekteer was.

Die resultate van die studie toon dat die CCES ' $n$ geldige metingsinstrument is van gemeenskapskollektiewe effektiwiteit in die geselekteerde steekproefpopulasie. Toekomstige studies kan daarop fokus om hierdie instrument verder kruiskultureel in verskillende Afrika-groepe en -kontekste en te valideer. 


\section{PREFACE}

\subsection{Article format}

For purposes of this mini-dissertation, which is part of the requirements for a professional master's degree, the article format as described by General Regulation A13.7 of the North-West University was chosen.

\subsection{Selected journal}

The target journal for submission of the current manuscript is the South African Journal of Psychology. The manuscript as well as the reference list has been styled to the journal's specifications.

\subsection{Letter of consent}

The letter of consent from the co-authors in which they grant permission that the manuscript Validation of a community collective efficacy scale in an African context may be submitted for purposes of a mini-dissertation by the first author, Wilmien van Straten, appears on the next page.

\subsection{Page numbering}

In the mini-dissertation, page numbers run through the whole document. For submission to the above-mentioned journal, manuscript numbering will be according to the requirements and thus start on the title page of the manuscript. 
NORTH-WEST UNIVERSITY

YUNIBESITI YA BOKONE-BOPHIRIMA

NOORDWES-UNIVERSITEIT

Academic Administration (Potchefstroom Campus)

SOLEMN DECLARATION

\section{Solemn declaration by student}

I

declare herewith that the mini-dissertation/dissertation/thesis entitled

which I herewith submit to the North-West University for purposes of compliance/partial compliance with the requirements set for the degree, is my own work and has not already been submitted to any other university.

I understand and accept that the copies that are submitted for examination are the property of the

University.

Signature of candidate University number

Signed at this day of 2007.

Declared before me on this day of 2007

Commissioner of Oaths:

\section{Declaration by supervisor/promoter}

The undersigned declares:

2.1 that the candidate attended an approved module of study for the relevant qualification and that the work for the course has been completed or that work approved by the Senate has been done

2.2 that the candidate is hereby granted permission to submit his/her mini-dissertation/dissertation or thesis

2.3 that registration/change of the title has been approved;

2.4 that the appointment/change of examiners has been finalised; and

2.5 that all the procedures have been followed according to the Manual for Postgraduate Studies.

Signature of Supervisor: Date: 
5. MANUSCRIPT

VALIDATION OF A COMMUNITY COLLECTIVE EFFICACY SCALE IN AN AFRICAN CONTEXT 
5.1 Instructions to authors: South African Journal of Psychology 


\title{
South African Journal of Psychology
}

\author{
Instructions to authors
}

\section{Submitting a manuscript}

SAJP is a peer-reviewed journal publishing empirical, theoretical and review articies on all aspects of psychology. Articles may focus on South African, African or international issues. Manuscripts to be considered for publication should be e-mailed to saip@unise ac.za. Include a covering letter with your postal address, email address, and phone number. The covering letter should indicate that the manuscript has not been published elsewhere and is not under consideration for publication in another journal. An acknowfedgement of receipt will be emailed to the author within a few days and the manuscript will be sent for review by three independent reviewers. Incorrectly structured or formatted manuscripts will not be accepted into the review process.

\section{Manuscript structure}

- The manuscript should be no longer than 30 pages and no shorter than 10 pages.

- First page: The full title of the manuscript, the name(s) of the author(s) together with their affiliations, and the name, address, and e-mail address of the author to whom correspondence should be sent.

- Second page: The abstract, formatted as a single paragraph, and no longer than 300 words. A list of at least six key words should be provided below the abstract, with semi-colons between words

- Subsequent pages: The text of the article. The introduction to the article does not require a heading.

- Concluding pages: A reference list, followed by tables and figures (if any). Each table or figure should be on a separate page. Tables and figures should be numbered consecutively and their appropriate positions in the text indicated. Each table or figure should be provided with a title (e.g., Figure 1. Frequency distribution of critical incidents). The title should be placed at the top for tables and at the bottom for figures.

\section{Manuscript format}

- The manuscript should be an MS Word document in 12-point Times Roman font with 1.5 line spacing. There should be no font changes, margin changes, hanging indents, or other unnecessarily complex formatting codes.

- American Psychological Association (APA) style guidelines and referencing format should be adhered to.

- Headings should start at the left margin, and should not be numbered. All headings should be in bold. Main headings should be in CAPITAL LETTERS.

- A line should be left open between paragraphs. The first line of a paragraph should not be indented.

- Use indents only for block quotes.

- In the reference list, a line should be left open above each reference. Do not use indents or hanging indents in the reference list.

\section{Language and punctuation}

Manuscripts should be written in English. As the SAJP does not employ a full-time or dedicated language editor, authors are requested to send their manuscripts to an external language specialist for language editing before submission. 


\title{
VALIDATION OF A COMMUNITY COLLECTIVE EFFICACY SCALE IN AN AFRICAN CONTEXT
}

\author{
Wilmien van Straten*, Q. Michael Temane, Marie P. Wissing
}

School for Psychosocial Behavioural Sciences, North-West Üniversity (Potchefstroom Campus), South Africa

*Correspondence to:

Wilmien van Straten

P/a Dr Q.M. Temane

School for Psychosocial Behavioural Sciences

North-West University (Potchefstroom Campus)

Private Bag X6001

Potchefstroom

2520

South Africa

wilmienvs@gmail.com

Michael.Temane@nwu.ac.za

Tel: +27182991721

Fax: +27182991730 


\begin{abstract}
The aim of this study was to validate a community collective efficacy scale in an African context. An abridged version of the Community Collective Efficacy Scale was validated in a cross-sectional survey design. Participants $(N=1050)$ from urban $(n=451)$ and rural $(n=599)$ areas completed the CCES and other measures of self-efficacy and psychological well-being. Results indicated a Cronbach alpha reliability coefficient of 0.72 and satisfactory inter-item correlations ranging between 0.17 and 0.25 . Significant correlations between the CCES and other measures of self-efficacy and psychological well-being indicated good criterion-related validity. Construct validity was supported by confirmatory and exploratory factor analysis. Exploratory factor analysis yielded one factor that relates to a sense of "we-ness". The CCES thus has good reliability and validity in an African context.
\end{abstract}

Key words: African context; psychological well-being; self-efficacy; collective efficacy; psychometric properties; reliability; validity 


\section{VALIDATION OF A COMMUNITY COLLECTIVE EFFICACY SCALE IN AN AFRICAN CONTEXT}

It is commonplace that human behaviour manifests in a social context. The social context of human behaviour has recently been a matter of discussion in cross-cultural research (Van de Vijver \& Leung, 1997), including findings that have indicated that experiences of psychological well-being also occur in various contexts and differ in regard to how people experience them (Wissing, Wissing, du Toit \& Temane, 2006). Findings indicated that there are differences in patterns of psychological well-being in individualist and collectivistic cultural contexts. In relatively more individualistic groups, satisfaction with life clusters with intrapsychological factors, but in a relatively more collectivistic cultural group satisfaction with life clusters with social facets (Wissing et al, 2006; Wissing \& van Eeden, 2002). In line with these observations, a previous study has shown that general self-efficacy beliefs and future-directed news was a separate factor in the case of individualistic groups, whereas it was part of a general psychological well-being component in a collectivistic group (Wissing et al, 2006).

Self-efficacy as an agentic construct has previously been used to determine group effectiveness (cf. Katz-Navon \& Erez, 2005; Pescosolido, 2003), as supported by substantive theorising, empirical evidence and validation in a Western and more individualistic context (cf. Bandura, 2001; Devonport \& Lane, 2006; Rodebough, 2006), among others. More recently, collective efficacy has also been used to determine how groups function, albeit in a more Western context such as in the case of self-efficacy, however, without a large body of empirical evidence and theorising. It is important to validate a community collective efficacy scale in this particular African context as it may have important outcomes for biopsychosocial health and psychological well-being.

As self-efficacy has been measured variously and extensively as a construct of positive psychological functioning, it will be used as a basis to argue the importance of collective efficacy later in the review. As defined by Bandura (2001), self-efficacy gives an indication of the levels of confidence individuals have in their ability to carry out a 
"course of action or attain specific goals. It refers to the individuals' judgments about their capabilities to act in a certain way in order to attain a goal as well as the ability to cope effectively with stressful situations (Devonport \& Lane, 2006; Karademas, 2006).

Self-efficacy affects human functioning in numerous ways and has an influence on choices regarding behaviour. Behaviour can be predicted by self-efficacy ratings, because such ratings allow participants to estimate their own behaviour based on whatever information they have about themselves and the situation at hand (Rodebaugh, 2006). For example, people will be more inclined to take on a task if they believe they can succeed. Self-efficacy also plays a role in motivation which affects human functioning in that people with high self-efficacy in a task are more likely to enlarge the effort and persist longer than those with low self-efficacy. Thought patterns and responses are also influenced by self-efficacy. People with high self-efficacy often see the bigger picture when approaching a task and thus take the more effective route of action. Perceptions also have a big role to play in influencing changes in self-efficacy. Bandura successfully demonstrates this point with the notion that people of differing degrees of self-efficacy perceive the world in fundamentally different ways (Bandura, 2001). Self-efficacy is of a cognitively evaluated nature and is influenced by four main . sources: performance accomplishments, vicarious experiences, verbal persuasion and the control of negative emotions (Devonport \& Lane, 2006).

High self-efficacy in a Western context is related to better well-being, regulation of the stress process, higher self-esteem and better physical condition (Devonport \& Lane, 2006; Karademas, 2006). Low self-efficacy is related to additional symptoms of stress, anxiety and depression, and also lower levels of subjective well-being (Devonport \& Lane, 2006; Karademas, 2006). Such individuals also have low self-esteem and harbour pessimistic thoughts about their accomplishments and personal development (Schwarzer \& Scholz, 2003). Devonport and Lane (2006) also identified a link between the use of active coping strategies and self-efficacy. The development of the ability to cope will result in an increase in coping efficacy, which will then contribute to an increase in outcome efficacy. People with higher self-efficacy will demonstrate the tendency to 
persist with a task despite difficulties and seek an acceptable resolution (Devonport \& Lane, 2006). As indicated by the literature reviewed, self-efficacy plays a contributing role in various aspects of psychological well-being and is an important construct to measure.

In recent years some discussions have begun around the contextual nature of selfefficacy, especially in relation to community collective efficacy (Carroll, Rosson and Zhou 2005; Drury \& Reicher, 2005). Collective efficacy can be defined as the representation of a group's shared belief in its conjoint capabilities to organise and carry out courses of action required to produce given levels of attainment (Watson, Chemers \& Preiser, 2001). Carroll et al. (2005) found that beliefs in collective efficacy influence how people use collective action to achieve the futures they seek, and a community collective efficacy scale was developed that could measure a community's beliefs about their collective capacities as a community (Carroll, Rosson \& Zhou 2005). Drury and Reicher (2005,p. 36) state that: "In previous research the issue of empowerment in social movements has commonly been addressed through the concept of efficacy. In some of these accounts, efficacy has been analyzed principally as a precondition for collective action".

Various scales have been designed to measure self-efficacy, for example the Generalized self-efficacy scale (Schwarzer \& Jerusalem, 1993), the New General self-efficacy scale (Chen, Gully \& Eden, 2001) and Community Collective Efficacy Scale (Carroll, et al., 2005). However, these scales were developed and applied in more Western and individualistic contexts. Carroll, Rosson and Zhou (2005) used their community collective efficacy scale to measure collective efficacy in a group of people using a community network. Therefore, in this study community collective efficacy is conceptualized in line with this latter conceptualisation as it captures a sense of "weness" as opposed to "I-ness".

Carroll et al. (2005) suggested that the CCES, which is used in this study as a measure of collective efficacy, can be used as a whole, in aggregate or as subscales in further 
research to measure different aspects of efficacy. In this study an abridged version of the CCES was used with seven items specific to collective efficacy. As suggested in the literature review, collective efficacy is in many ways the extension of the self-efficacy beliefs about the shared capacities of the group in which people participate regarding joint activities and the successful achievement of these activities as a group. People's beliefs in collective efficacy influence the futures they seek to achieve: through collective action, the use of available resources, effort expended and the persistence they will exercise in an endeavour to achieve goals.

The foregoing insights about both self-efficacy and collective efficacy were gained primarily from a Western, more individualistic context, and the question can be asked how self-efficacy and collective efficacy will manifest in an African, more collectivistic context. Drury and Reicher (2005) have indicated that recent research in efficacy theory has been extended from an individual to a more collectivistic approach. It is also known that researchers have broadly distinguished between societies as either independent/individualistic and interdependent/collectivistic in orientation (Lansford, Antonucci, Akiyama \& Takahashi, 2000).

Individualism and collectivism are complex constructs and have been defined in various ways (Green, Deschamps \& Páez, 2005). Typical attributes associated with individualism are independence, autonomy, self-reliance, uniqueness, achievement orientation, and competition. Individualists have control over and take responsibility for their actions. Collectivism, in turn, is associated with a sense of duty toward one's group, interdependence with others, a desire for social harmony, and conformity with group norms. In this view, the norms and demands of extended family or the close-knit community determine the behaviour and attitudes of collectivists (Green, Deschamps \& Páez, 2005 ; Lansford et al, 2000; Triandis, 2001). Some research supports the idea that in a collectivist culture people develop their self-efficacy from those around them, whereas in an individualistic society individuals construct their self-efficacy from their own individualistic experiences of success and failure (Pulford, Johnson \& Awaida, 2005; Earley, 1994). 
Typically individualistic traits are used to characterise people from Western contexts (Western Europe, North America, Australia), whereas collectivist characteristics are used to describe non-Western (Asian, South American, African) personalities (Green, Deschamps \& Páez, 2005). In a study by Klassen (2004) it was found that self-efficacy beliefs were higher among individuals from Western, individualistic cultures than among individuals from Asia, seen as non-Western and more collectivistic. The conclusion was made that collective efficacy is more prominent among people with a collectivistic orientation. Thus, there should be scales available to measure this construct in an African, more collectivistic context.

Based on the foregoing it can be argued that self-efficacy and collective efficacy manifest themselves differently in individualistic and collectivistic societies. It would appear that collective efficacy is a better construct to use in reference to a collectivistic/African society. As mentioned earlier, scales measuring self-efficacy were developed and applied in a Western culture and can thus beg the question whether these scales can be applied as they are and on a large scale in an African collectivistic culture. The objective of this study is thus to validate CCES in an African collectivistic society.

\section{METHOD}

\section{Design}

A cross-sectional survey design was used in this study.

\section{Participants}

Participants from a relatively more collectivistic South African cultural context were selected for this study (further details are given in the procedure section for the context of the study). Setswana-speaking participants $(N=1050)$ from both rural $(n=599)$ and urban $(n=451)$ areas of the North-West Province of South Africa were selected. Two hundred and twenty nine participants were from Ikageng (an established urban area outside Potchefstroom), 215 participants came from an informal urban settlement adjacent to Ikageng, 281 participants were from Ganyesa (an urban rural settlement almost bordering 
Botswana) and 318 participants were from Tlakgameng (a deep rural settlement located 35 kilometres from Ganyesa). There were 392 men and 649 women in the sample. Ages were distributed as follows: 228 participants were between the ages of 30 and 40 years, 4.16 participants were between the ages of 41 and 50 years, 248 participants were between the ages of 51 and 60 years, 106 participants were between the ages of 61 and 70 years, 29 participants were between the ages of 71 and 80 years and 2 participants were over 80 years of age. Disparity in numbers is due to incomplete and/or missing data on some of these demographic characteristics.

\section{Measuring Instruments}

Community Collective Efficacy Scale (abridged) (CCES) (Carroll, Rosson \& Zhou, 2005). The CCES measures the community's ability to succeed in joint activities. Carroll, Rosson and Zhou (2005) offer the opinion that collective efficacy beliefs would influence community-oriented behaviours, including planning and use of shared resources and a willingness to persist in spite of internal conflicts, social concerns or political challenges. As the original 9-item scale was developed for a community computing context, only 7 items were selected from the original CCES for use in the present study as the rest of the items in the scale by Carroll et al. (2005) were not relevant to community collective efficacy. Items were selected that had a bearing on normative community functioning in terms of "managing tradeoffs and conflicts". The higher the score obtained in the CCES the stronger the feeling of belonging, and the higher the chance that the individual will be an activist in the relevant community (Carroll, Rosson $\&$ Zhou, 2005). Carroll, Rosson and Zhou (2005) report an internal reliability of 0.86 .

Generalized Self-Efficacy Scale (GSE) (Schwarzer \& Jerusalem, 1993). The GSE is a 10 -item scale that provides measurement of the strength of an individual's belief in his/her ability to react successfully to difficult situations, minimum pressures and his/her ability to cope with any associated setbacks. Schwarzer and Jerusalem (1993) reported Cronbach alphas between 0.82 and 0.93 . They also reported satisfying construct validity for the GSE. In the current study the Cronbach alpha obtained was 0.66 . 
New General Self-Efficacy Scale (NGSE) (Chen, Gully \& Eden, 2001). The NGSE (an 8-item scale) was developed to measure an individual's tendency to view the self as capable of meeting task demands in various contexts. Validation studies have indicated that the NGSE measures a construct that is related to, but distinct from both self-esteem and situational self-efficacy (Chen, Gully \& Eden, 2001). In the current study the internal reliability obtained was 0.74

Sense of Coherence Scale (SOC) (Antonovsky, 1987, 1993). The 29-item scale measures an individual's way of experiencing the world and his/her life in it. Sense of Coherence consists of three core components, namely comprehensibility, manageability and meaningfulness. The SOC correlates positively with psychological and physical well-being (Wissing \& Van Eeden, 2002). Antonovsky (1993) reports internal reliability indices of the SOC that vary from 0.78 to 0.93 and test-retest reliability indices that vary from 0.56 to 0.96 . The scale is reliable and valid for use in South Africa (Wissing, Thekiso, Stapelberg, Van Quickelberge, Choabi, Moroeng \& Nienaber, 1999). The Cronbach alpha reliability index was 0.80 in the current study.

Affectometer 2 (short version) (AFM) (Kammann \& Flett, 1083). The AFM measures a general sense of well-being or general happiness. The AFM measures psychological well-being on an affective level by determining the balance between negative and positive affect (Kammann \& Flett, 1983). Two 20-item forms of the AFM exist: the one is a sentence item scale while the other one is an adjective item scale. The former was used in the present study. The measure consists of three sub-scales: Positive Affect (PA), Negative Affect (NA) and Positive-Negative-Affect-Balance (PNB). A higher level of well-being is obtained when PA is higher than NA (Kammann \& Flett, 1983). Cronbach alpha-reliability indices of 0.88 and 0.93 were reported (Kammann \& Flett, 1983). Wissing et al. (1999) found the scale applicable in the South African context. In the current study, Cronbach alphas of 0.66 for PA and 0.72 for NA were found.

Satisfaction with Life Scale (SWLS) (Diener, Emmons, Larsen \& Griffin, 1985). This 5-item scale was developed to give an indication of general satisfaction with life. Quality 
of life is evaluated on a cognitive-judgmental level according to own criteria. The reliability index of the SWLS according to Diener et al. (1985) is 0.82 and its Cronbach alpha-reliability index is 0.87 . The scale showed sufficient psychometric properties for use in South Africa (Wissing et al., 1999). The SWLS Cronbach alpha reliability index obtained in the current study is 0.7

General Health Questionnaire (Goldberg \& Hillier, 1979). The 28-item GHQ's aim is to detect symptoms of mental disorder and to differentiate between groups that are considered a general or normal class of psychopathology. The scale consists of 4 subscales, namely Somatic Symptoms (SS), Anxiety and Insomnia (AI), Social Dysfunction (SD) and Severe Depression (DS). Goldberg and Hillier (1979) reported Cronbach alphas that vary from 0.82 to 0.86 . Wissing et al (1999) reported acceptable reliability and validity from a study with a Setswana-speaking group. The Cronbach alpha reliability index in the current study for the full scale was 0.72 and for the sub-scales respectively 0.75 for $\mathrm{SS}, 0.77$ for $\mathrm{AS}, 0.55$ for $\mathrm{SD}, 0.77$ for $\mathrm{DS}$ and 0.89 for the total scale.

\section{Procedure}

This study entails and cuts across the PURE-SA (Prospective Urban and Rural Epidemiological - South Africa project), coordinated by Kruger and conducted by participants in AUTHeR (Vorster, 2006) and the Fortology project (FORT 2= Fortology: Understanding and promoting psychosocial health, resilience and strengths in an African context, coordinated by Wissing, 2006). The participants were selected in the context of the PURE-project (a larger multi-disciplinary project). The questionnaires selected and used were part of the FORT 2-project. The questionnaires were translated into Setswana and then back translated into English and finalised by comparing the two English versions of the questionnaires in a research committee approach (Van de Vijver \& Leung, 1997). No major translation problems were encountered when comparing the original and back-translated questionnaires. Sixteen fieldworkers, from the areas where the research was conducted, were trained and assisted in the administration of the questionnaires, in a structured interview format. The fieldworkers were bilingual and 
capable of speaking and understanding both English and Setswana. The Setswana version was used for the data collection.

\section{Ethical Aspects}

Approval for this study was obtained from the Ethics committee of the North-West University. The approval number for the PURE-project is 04M10, and for the FORT2project it is $05 \mathrm{~K} 10$. Informed consent was obtained from all participants prior to their participation and the personal information of participants was treated confidentially.

\section{Data Analysis}

Descriptive statistics and reliability indices were determined by using Statistica. Clark and Watson (1995) stated that contemporary researchers classify reliabilities between 0.60 and 0.70 as good or adequate, whereas Nunnally and Bernstein (1994) recommended a reliability of 0.70 as sufficient in construct validation research. The Cronbach alpha mainly measures internal consistency and could be limited in establishing unidimensionality (Clark \& Watson, 1995). Inter-item correlations were therefore also determined as these give an indication of the extent to which the items measure a single construct or factor (Smith \& McCarthy, 1995). These correlations should be between 0.15 and 0.50 for a broad construct (Clark \& Watson, 1995).

Criterion-related validity of the CCES was determined by using correlations with other scales measuring self-efficacy and psychological well-being. Construct validity was established, firstly by conducting confirmatory factor analysis using structural equation modelling. Indices of fit are reported by using RMSEA, GFUAGFI, NFI/NNFI. The overall amount of error in the hypothesised model-data fit relative to the number of estimated parameters or the complexity of the model are indicated by the RMSEA. According to Browne and Cudeck (1993) a value of 0.05 or less indicates a good fit. The GFI indicates the relative amount of variance and co-variance in the sample predicted by estimates of the population. An index of 0.90 indicates a good model fit (Muncer \& Campbell, 2002). The most common comparative fit index is the Normed Fit Index (NFI), which tests if the model differs from the null hypothesis and that none of the 
variables are related to each other (Bollen \& Long, 1993). Secondly construct validity was determined via an exploratory factor analysis of the CCES using the maximum likelihood method of factor extraction with oblique rotation to determine the number of factors inherent in the scale.

\section{RESULTS}

\section{Descriptive statistics and reliability of self-efficacy measures used in the study}

Descriptive statistics and reliability indices for measures used in this study are reported in Table 1. Cronbach alpha reliability coefficients were $0.72,0.66,0.74$ for the CCES, GSE and NGSE respectively as measures of both collective efficacy and self-efficacy. Interitem correlations, which serve as a straightforward indicator of internal consistency (Clark \& Watson, 1995), yielded values ranging from 0.17 to 0.25 . Clark and Watson (1.995) indicated that values between 0.15 and 0.50 fall within the desirable range for inter-item correlations. It can thus be concluded that the internal consistency is satisfactory. Item-total correlations for the CCES ranged between 0.33 and 0.48 .

[Table 1]

\section{Criterion-related validity of the CCES}

Correlations of the CCES with other scales measuring self-efficacy and psychological well-being were used to determine criterion-related validity. Measures of psychological well-being used for this criterion validity were tested in studies based on a similar context (Wissing et al., 2006). Results of the criterion validity of the CCES are reported in Table 2. All the correlations are statistically significant. The highest correlation was found between the GSE and NGSE, with a value of 0.50 .

[Table 2] 


\section{Confirmatory factor analysis}

Confirmatory factor analysis of the CCES was determined by using Structural Equation Modelling in SEPATH (Statistica version 7.0). The results of the study show that overall, the CCES may be a valid measure of community collective efficacy (RMSEA $=0.03$; $\mathrm{CI}=0.02 / 0.05$ ). According to Browne and Cudeck (1993) RMSEA should be 0.05 or less to indicate good fit. The GFI/AGFI, NFI/NNFI were also consistent with good indications of fit, as they were above $0.9(\mathrm{Yu}, 2002)$. The results obtained for these measures of fit were as follows: GFI/AGFI $=0.991 / 0.982$, and NFI $/ \mathrm{NNFI}=0.965 / 0.968$

\section{Exploratory factor analysis}

An exploratory factor analysis, using the maximum likelihood method of factor extraction with oblique rotation, was conducted on the CCES and yielded one factor. This factor relates to a sense of "we-ness" where the community is able to achieve particular goals together. Results are reported in Table 3. The eigen value for the first factor is 2.64 , explaining $37.64 \%$ of the variance. The Kaiser-Meyer-Olkin measure of Sampling Adequacy yielded a value of 0.83 , which is in accordance with the criteria set by Tabachnick and Fidell (2001). The Goodness-of-fit Test yielded a Chi-square of 35,084 ( $\mathrm{df}=14$. and Sig. $=0.01$ ). Item 6 on the CCES had the lowest communality and the lowest coefficient of determination $\left(R^{2}\right)$. Generally, communalities must have a minimum of at least 0.4 to be included in a factor analysis (cf. Tabachnik \& Fiddell, 2001).

[Table 3]

Overall, the results show that the CCES is valid for use in the sample selected for this study and has an acceptable reliability coefficient. Secondly, the results also show that the CCES is related to other measures of self-efficacy and psychological well-being. 


\section{DISCUSSION}

The abridged version of the CCES showed good reliability and validity in this Setswana-speaking African group, suggesting that the measure could be used to measure collective efficacy in similar contexts. Standards set in the literature for reliability and validity were adequately met (cf. Clark \& Watson, 1995; Nunnally \& Bernstein, 1994; Browne \& Cudeck, 1993).

No data regarding the CCES's descriptive statistics have been published and thus there were no existing data against which to compare the current findings. The mean of the CCES lies well within the minimum and maximum scores of the scale itself and thus suggest a good central tendency for the scale. The Cronbach alpha reliability and interitem correlations were within the expected ranges (cf. Clark \& Watson, 1995).

All correlations of the CCES with other scales measuring self-efficacy and psychological well-being were statistically significant and supported criterion-related validity. The high correlation between the GSE and NGSE was expected, since both scales measure an individual's belief in himself/herself to accomplish certain tasks. As expected, the correlations between the CCES and the two self-efficacy scales were also high and significant.

Based on construct validity findings yielded by the results, the CCES is valid for the sample used in this study. The RMSEA value of this model was a good fit (Browne \& Cudeck, 1993). The GFI/AGFI and NFI/NNFI also indicated a good fit. These results only represent a specific cultural context and thus future studies may test empirically the validity of this scale in other contexts such as work, church groups, rugby teams and so forth.

Exploratory factor analysis showed high communalities and yielded one factor (except for item 6 , which had a lower communality than expected). This factor relates to a sense 
of cooperating actively among members of the community to collectively instil a sense of "we-ness", therefore meeting the needs of the community. Based on the principles of collectivism, people in collectivistic cultures are more interdependent within their groups and families, which could explain the sense of "we-ness" (Triandis, 2001). Research further suggests that in a collectivist culture people develop their self-efficacy from those around them, which also supports the idea of "we-ness" (Pulford, Johnson \& Awaida, 2005; Earley, 1994).

The findings also confirm the observation by Carroll et al. (2005), who developed the scale for a computing community. The one factor yielded by the 7 item scale used in this study explained $37.64 \%$ of the variance. This finding also correlates with the finding by Carroll et al. (2005) that $40.5 \%$ of the variance explained this factor. In line with these findings it can be concluded that community collective efficacy exists in this sample, even though measured with an instrument that was meant more for a typically individualistic community.

Item 6 yielded the lowest communality and the lowest coefficient of determination $\left(\mathrm{R}^{2}\right)$. The item reads "I am confident that we can be united in the community vision we present to outsiders". The key concept in this item relates to community vision. Results in this study indicate that an aspect such as community vision may not be a main point of concern for communities in collectivistic societies since research suggests that collective societies are mainly characterised by a sense of duty towards the group, interdependence with others, a desire for social harmony and conformity with group norms (Green, Deschamps \& Paez, 2005; Lansford, Antonucci, Akiyama \& Takahashi, 2000; Triandis, 2001). Excluding this item from the exploratory factor analysis yields lower communalities and a lower coefficient of determination of the other items, thus it might be suggested that the item should be retained, but rephrased/adapted in an African context to "We see important things through the same eyes in our community".

This study contributes to the limited theory regarding collective efficacy in an African. context. A practical implication is the reliability and validity of the CCES as a measure 
for further use in, for example, epidemiological studies. Limitations of this study could be that the content of certain items had lower relevance or familiarity in an African context and should take socio-economic circumstances into account, such as item 6 . Greater control of administration of the scale can be done by the improvement of the training and by controlling fieldworkers.

Future research could investigate the use of the CCES in rural versus urban areas. The application of the CCES in other languages or cultures could also be explored. By including data analysis across different demographic, cultural and language groups, the validity of the CCES could be enhanced.

The research aim was to validate a community collective efficacy scale in an African collectivistic society. The CCES was used as an exploratory measure. It can be concluded that the CCES has good reliability and indications of validity in an African collectivistic society and can be used to measure community collective efficacy in the sample used in this study. 


\section{REFERENCES}

Antonovsky, A. (1987). Unraveling the mystery of health: how people manage stress and stay well. San Francisco: Jossey-Bass.

Antonovsky, A. (1993). The structure and properties of the Sense of Coherence Scale. Social Science and Medicine, 36, 725-733.

Bandura, A. (2001) Social cognitive theory: an agentic perspective. Annual Review Psychology, 52, 1-26.

Bollen, K.A. and Long, J.S. (1993). Testing structural equation models (pp. 136-162). London: Sage.

Browne, M. W. \& Cudeck, R. (1993). Alternative ways of assessing model fit. In: Bollen, K. A. \& Long, J. S. (Eds.) Testing Structural Equation Models. pp. 136-162. Beverly Hills, CA: Sage.

Carroll, J.M., Rosson, M.B. \& Zhou, J. . (2005). Collective efficacy as a measure of community. Proceedings as human factors in computing systems: CHI 2005. New York: ACM.

Chen, G., Gully, S.M. \& Eden, D. (2001). Validation of a new general self-efficacy scale. Organizational Research Methods, 4 (1), 62-83.

Clark, L.A. \& Watson, D. (1995). Constructing validity: Basic issues in objective scale development. Psychological assessment, 7 (3), 309-319.

Devonport, T.J., \& Lane, A.M. (2006). Relationships between self-efficacy, coping and student retention. Social Behavior and Personality, 34(2), 127-138. 
Diener, E., Emmons, R., Larsen, R.J. \& Griffin, S. (1985). The Satisfaction with Life Scale. Journal of Personality Assessment, 49(1), 71-75.

Drury, J., \& Reicher, S. (2005). Explaining enduring empowerment: A comparative study of collective action and psychological outcomes. European Journal of Social Psychology, 35, 35-58.

Earley, P.C (1994). Self or Group? Cultural effects of training on self-efficacy and performance. Administrative Science Quarterly, 39, 89-117.

Green, E.G., Deschamps, J. \& Páez, D. (2005). Variation of individualism and collectivism within and between 20 countries. A typological analysis. Journal of Crosscultural Psychology. 36(3), 321-339.

Goldberg, D.P. \& Hillier, V.F. (1979). A scaled version of the General Health Questionnaire. Psychological Medicine, 9, 139-145.

Kammann, R. \& Flett, R. (1983). Affectometer 2: a scale to measure current levels of general happiness. Australian Journal of Psychology, 35, 259-265.

Karademas, E.C. (2006). Self-efficacy, social support and well-being. The mediating role of optimism. Personality and Individual Differences, 40 1281-1290.

Katz-Navon, T.Y. \& Erez, M. (2005). When collective efficacy- and self-efficacy affect team performance: The role of task interdependence. Small group research, 36(4), 437 465.

Klassen, R.M. (2004). Optimism and realism: A review of self-efficacy from a crosscultural perspective. International Journal of Psychology, 39(3), 205-230. 
Lansford, J. E., Antonucci, T. C., Akiyama, H., \& Takahashi, K. (2005). A quantitative and qualitative approach to social relationships and wellbeing in the United States and Japan. Journal of Comparative Family Studies, 36, 1-23.

Muncer, S. \& Campbell, A. (2004). Confirmatory factor analysis and the factor structure of Expagg in context: A reply to Forrest et al., 2002. Aggressive Behavior, 30, 146-157.

Nunnally, J.C. \& Bernstein, I.H. (1994). Psychometric theory (3rd ed.). New York: McGraw-Hill.

Pescosolido, A.T. (2003). Group efficacy and group effectiveness: The effects of group efficacy over time on group performance and development. Small group research, 34(1), $20-42$.

Puilford, B.D., Johnson, A. \& Awaida, M. (2005). A cross-cultural study of predictors of self-handicapping in university students. Personality and Individual Differences, 39, 727-737.

Rodebaugh, T.L. (2006). Self-efficacy and social behavior. Behaviour Research and Therapy, 44(12), 1831-1838

Smith, G.T. \& McCarthy, D.M. (1995). Methodological considerations in the refinement of clinical assessment instruments. Psychological Assessments, 7(3), 300308.

Schwarzer, R. \& Jerusalem, M. (1993). Measurement of perceived self-efficacy: Psychometric scales for cross-cultural research. Berlin: Freie Universität.

Schwarzer, R., \& Scholz, U. (2003) Cross-cultural assessment of coping resources: The general perceived self-efficacy scale. 
Tabachnick, B.G., \& Fidell, L.S. (2001). Using multivariate statistics. $4^{\text {th }}$ ed. New York: Harper Collins.

Triandis, H.C. (2001). Individualism-collectivism and personality. Journal of Personality, 69(6), 907-924.

Van de Vijver, F.J.R. \& Leung, K. (1997). Methods and data analysis for cross-cultural research. Newbury Park, C.A : Sage.

Vorster, H. H. (2006). Africa Unit for Trans-disciplinary Health Research (AUTHeR): Annual report and strategic planning document. Unpublished document, North-West University: Potchefstroom Campus, Potchefstroom.

Watson, C.B., Chemers, M.M. \& Preiser, N. (2001). Collective efficacy: A multilevel analysis. Journal for Personality and Social Psychology, 27(8), 1057-1068.

Wissing, M.P., Thekiso, S., Stapelberg, R., Van Quickelberge, L., Choabi, P., Moroeng, C. \& Nienaber, A. (1999, July). The psychometric properties of scales measuring psychological well-being in an African group: the THUSA study. Paper presented at the International Africa Psychology Congress. Durban, South Africa.

Wissing, M.P., \& van Eeden, C. (2002). Empirical clarification of the nature of psychological well-being. South African Journal of Psychology, 32(1), 32-44.

Wissing, M.P., Wissing, J.A.B., du Toit, M.M., \& Temane, Q.M. (2006) Patterns of psychological well-being and satisfaction with life in a cultural context. Dimensions of Well-being: Research and Intervention; Delle Fave, A. (ed.). Milano, Italy: FrancoAngeli. 
Wissing, J.A.B., Wissing, M.P., du Toit, M.M., Temane, Q.M. (2006, April) Psychometric properties of scales measuring psychological well-being in a South African context: The FORT and POWIRS projects. SA Conference on Positive Psychology: Individual, Social and Work Wellness, Potchefstroom, South Africa.

Wissing, M.P. (2006). Understanding and promoting psychosocial health, resilience and strength in an African context. NRF research project - protocol, NWU, Potchefstroom.

Yu, C. (2002). Evaluating cut-off criteria of model fit indices for latent variable models with binary and continuous outcomes. A dissertation submitted in partial satisfaction of the requirements for the degree Doctor of Philosophy in Education. UCLA. 
Table 1: Descriptive statistics of self-efficacy measures used in the study

\begin{tabular}{lllll}
\hline VARIABLE & M & SD & $\begin{array}{l}\text { RANGE } \\
\text { Min-Max }\end{array}$ & $\alpha$ \\
\hline CCES & 23.04 & 4.80 & $07-35$ & 0.72 \\
GSE & 27.84 & 4.47 & $10-40$ & 0.66 \\
NGSE & 28.10 & 5.28 & $8-40$ & 0.74 \\
\hline
\end{tabular}

Note: CCES = Community Collective Efficacy Scale (abridged); GSE = Generalized Self-Efficacy Scale; NGSE = New General Self-Efficacy Scale 
Table 2: Correlations of CCES with measures of self-efficacy and psychological well-being for criterion validity

\begin{tabular}{|c|c|c|c|c|c|c|c|}
\hline & 1 & 2 & 3 & 4 & 5 & 6 & 7 \\
\hline 1. CCES & \multicolumn{7}{|c|}{1.00} \\
\hline 2. GSE & \multicolumn{7}{|c|}{$0.38 * * 1.00$} \\
\hline 3. NGSE & \multicolumn{7}{|c|}{$0.41 * * 0.50 * * 1.00$} \\
\hline 4. SOC & \multicolumn{7}{|c|}{$0.19 * * 0.19 * * 0.29 * * 1.00$} \\
\hline 5. AFM & \multicolumn{7}{|c|}{$0.17^{* *} 0.31 * * 0.36 * * 0.48 * * 1.00$} \\
\hline 6. SWLS & \multicolumn{7}{|c|}{$0.12^{* *} 0.19^{* *} 0.07 * \quad 0.18^{* *} 0.35^{* *} 1.00$} \\
\hline 7. GHQ & \multicolumn{7}{|c|}{$-0.10^{* *}-0.16^{* *}-0.23^{* *}-0.52^{* *}-0.47^{* *}-0.11^{* *} 1.00$} \\
\hline
\end{tabular}

Note: CCES = Community Collective Efficacy Scale (revised); GSE = Generalized SelfEfficacy Scale; NGSE $=$ New General Self-Efficacy Scale; $S O C=$ Sense of Coherence Scale / Antonovsky Orientation to Life Questionnaire; AFM = Affectometer 2; SWLS = Satisfaction With Life Scale; $\mathrm{GHQ}=$ General Health Questionnaire

$* * 0.01$ Correlations are significant at the 0.01 level (2-tailed).

*0:05 Correlations are significant at the 0.05 level (2-tailed). 
Table 3: Exploratory factor analysis using the maximum likelihood method of factor extraction, with Oblimin rotation

\begin{tabular}{llll}
\hline VARIABLE & $\begin{array}{l}\text { FACTOR } \\
\text { LOADINGS }\end{array}$ & COMM & $\mathbf{R}^{2}$ \\
\hline CCES 1 & 0.58 & 0.44 & 0.24 \\
CCES 2 & 0.55 & 0.41 & 0.23 \\
CCES 3 & 0.52 & 0.38 & 0.21 \\
CCES 4 & 0.45 & 0.30 & 0.14 \\
CCES 5 & 0.59 & 0.44 & 0.24 \\
CCES 6 & 0.39 & 0.25 & 0.12 \\
CCES 7 & 0.56 & 0.41 & 0.22 \\
\hline
\end{tabular}




\section{Appendix A}

\section{COMMUNITY COLLECTIVE EFFICACY SCALE (CCES) (ABRIDGED) \\ (Carroll, Rosson, Zhou, 2005)}

Instructions:

Indicate the extent to which each statement applies to you

\begin{tabular}{|c|c|c|c|c|}
\hline $\begin{array}{l}\text { Strongly } \\
\text { disagree }\end{array}$ & Disagree & Uncertain & Agree & Strongly agree \\
\hline 1 & 2 & 3 & 4 & 5 \\
\hline
\end{tabular}

\begin{tabular}{|c|l|c|c|c|c|c|}
\hline 1 & $\begin{array}{l}\text { We can resolve crises in the community without any } \\
\text { negative after effects. }\end{array}$ & 2 & 3 & 4 & 5 \\
\hline 2 & $\begin{array}{l}\text { I am convinced that we can improve the quality of life in } \\
\text { the community, even when resources are limited or } \\
\text { become scarce. }\end{array}$ & 1 & 2 & 3 & 4 & 5 \\
\hline 3 & $\begin{array}{l}\text { Our community can cooperate in the face of difficulties } \\
\text { to improve the quality of community facilities. }\end{array}$ & 1 & 2 & 3 & 4 & 5 \\
\hline 4 & $\begin{array}{l}\text { Despite work and family obligations, we can commit } \\
\text { ourselves to common community goals. }\end{array}$ & 1 & 2 & 3 & 4 & 5 \\
\hline 5 & $\begin{array}{l}\text { As a community, we can handle mistakes and setbacks } \\
\text { without getting discouraged. }\end{array}$ & 1 & 2 & 3 & 4 & 5 \\
\hline 6 & $\begin{array}{l}\text { I am confident that we can be united in the community } \\
\text { vision we present to outsiders. }\end{array}$ & 1 & 2 & 3 & 4 & 5 \\
\hline 7 & $\begin{array}{l}\text { The people of our community can continue to work } \\
\text { together, even when it requires a great deal of effort. }\end{array}$ & 1 & 2 & 3 & 4 & 5 \\
\hline
\end{tabular}

